\title{
Narasi Sejarah Novel Tambora Karya Agus Sumbogo: Kajian Sosiologi Sastra
}

\author{
Ardini Mulyadi ${ }^{*}$, Ida Bagus Jelantik SP $^{2}$ \\ ${ }^{[12]}$ Program Studi Sastra Indonesia, Fakultas Ilmu Budaya-Universitas Udayana \\ ${ }^{1}$ [ardinimulyadi1@gmail.com], ${ }^{2}$ [idabagusjelantik@yahoo.co.id] \\ *Corresponding Author
}

\begin{abstract}
Abstrak
Novel Tambora karya Agus Sumbogo dipilih sebagai objek penelitian karena beberapa alasan. Pertama, novel Tambora menceritakan perjalanan Lesly menuju Tambora untuk mengembalikan barang berharga milik masyarakat Tambora. Kedua, novel Tambora mengungkap sejarah dan fenomena yang terjadi sebelum meletusnya Gunung Tambora. Ketiga, novel Tambora mengisahkan kehancuran masyarakat ketiga kesultanan yang berada di daerah Gunung Tambora akibat adu domba Belanda. Masalah yang dibahas ialah struktur, sejarah, dan aspek sosial ketiga kesultanan yang ada di daerah Gunung Tambora. Teori yang digunakan dalam analisis ini, yaitu teori struktur yang menekankan pada unsur penokohan, alur, dan latar. Selain itu, penelitian ini juga membahas sejarah yang terungkap sebelum meletusnya Gunung Tambora. Dilanjutkan dengan teori sosiologi sastra yang tercantum dalam buku Burhan Nurgiyantoro, 2005. Metode yang digunakan untuk mengumpulkan data adalah metode studi pustaka dengan teknik lanjutan berupa teknik catat. Kemudian untuk menganalisis data digunakan metode deskripsi analisis dengan cara mendeskripsikan hasil pengolahan data yang telah dilakukan. Penokohan dibagi menjadi tokoh utama dan tokoh tambahan. Tokoh utama dalam Novel Tambora, yaitu Lesly, tokoh tambahan, yaitu Uma, Jeff, dan Wayan. Alur dibagi menjadi tiga tahapan, yaitu tahap awal, tahap tengah, dan tahap akhir. Alur yang digunakan dalam novel Tambora ialah alur campuran. Kemudian, latar dibedakan menjadi tiga, yaitu latar tempat, latar waktu, dan latar sosial. Penelitian ini juga menggambarkan sejarah meletusnya Gunung Tambora, baik berupa fakta maupun fiksi. Berdasarkan kajian sosiologi sastra terdapat beberapa aspek yang terungkap dalam Novel Tambora, yaitu aspek moral yang baik dan buruk, aspek politik adu domba, aspek ekonomi masyarakat Tambora, aspek kemasyarakatan yang menjelaskan baik buruk hubungan antarkesultanan, dan aspek budaya yang melukiskan adat istiadat yang hampir punah.
\end{abstract}

Kata kunci: Struktur, sosiologi sastra, dan Tambora

Abstract
The data of this study were taken from an Indonesia novel entitled 'Tambora' by Agus Sumbogo
(2015) as a research objective caused some factors. First, 'Tambora' novel telling us the
beginning of Lesley journey to return the precious things of Tambora's people. Second,
'Tambora' novel describe the story and phenomena that exist before Mount Tambora was
erupted. Third, 'Tambora' novel related to the destruction of the third sultanate people that is
located close around Mount Tambora caused by Dutch confront Devide et Impera. The writer
have analyzed the problems in the novel, such as structures, history, and social aspect of the
third sulatanate which exist in Tambora area. The theory used in this study was structural
theory applied to analyze the characters, especially the element of characterization, plot, and
setting. Moreover, this study also presented the history revealed before Mount Tambora was
erupted. The writer also uses the sociology of literature theory taken from the book by Burhan


Nurgiyantoro 2005. The method used in collecting the data was literature review method with continuation technique in form of note taking technique. Afterwards, the method used in this research is descriptive analysis to describe the result related to the data that have been analyzed. Characterization in this novel can be divided into two, major character and additional characters. The major character in 'Tambora' novel named Lesley and additional characters are Uma, Jeff, and Wayan. The plot can be divided into three, they were beginning, middle, and an end. The plot used in Tambora novel is mixing plot. Afterward, the setting is divided into three, place, time, and social of story. This study also illustrates the history of the eruption of Mount Tambora either in fact or fiction. Based on sociology of literature theory, there are found some aspcets revealed in the Tambora novel, that is good and bad moral aspects, political aspect Devide et Impera, economic aspects of Tambora people, social aspect of the good and bad sultanates relations, and cultural aspect to do the tradition that almost extinguished.

Keywords: Structure, sociology of literature, Tambora

\section{Latar Belakang}

Karya sastra tidak ada begitu saja, tetapi diciptakan oleh sastrawan untuk dinikmati, dihayati, dipahami, dan dimanfaatkan oleh masyarakat. Sastra menampilkan gambaran kehidupan dan kehidupan tak lain adalah suatu kenyataan sosial. Kehidupan sosial mencakup hubungan antarmasyarakat, antarmanusia dan antarperistiwa yang terjadi dalam batin seseorang (Damono, 2014:1).

Karya sastra yang bersifat naratif menceritakan serangkaian kejadian, tindakan, keadaan secara berurutan dari permulaan sampai akhir sehingga terlihat rangkaian hubungan satu sama lain. Bahasanya berupa paparan yang gayanya bersifat naratif. Contoh jenis karangan ini adalah biografi, roman, novel, dan cerpen (Widjono, 2007:175 dalam blog Rusyanti, 2015).

Novel Tambora merupakan novel pertama Agus Sumbogo yang dipublikasikan dan hasil petualangan rohaninya selama bertahun-tahun di pulau Sumbawa. Novel ini dipilih sebagai objek penelitian karena menarik untuk diteliti nilai sosialnya dengan pendekatan sosiologi sastra. Hal ini dikarenakan novel Tambora dilatarbelakangi oleh masalah sosial kemasyarakatan, terutama masyarakat yang ada di sekitar wilayah Gunung Tambora. Novel ini membahas sejarah dan fenomena yang terjadi sebelum meletusnya Gunung Tambora tahun 1815. Diceritakan pula pula bagaimana kehancuran yang menimpa tiga kerajaan yang berada di wilayah Gunung Tambora sendiri, yakni, kerajaan Tambora, Pekat, dan Sanggar.

Alasan novel Tambora dijadikan objek penelitian, yaitu pertama novel Tambora mengandung unsur sejarah. Alasan kedua pemlihan novel ini sebagai objek kajian karena menggambarkan sejarah letusan Gunung Tambora di Pulau Sumbawa, Provinsi Nusa Tenggara Barat. Perjalanan gadis bernama Lesly dan tiga temannya ke masa lalu untuk mengembalikan barang berharga masyarakat Tambora berupa kopiah emas yang tersimpan di dalam kotak hitam. Kopiah tersebut diambil oleh ayah Lesly, Profesor Thomas ketika melakukan ekspedisi penggalian barang bersejarah yang terkubur ketika Gunung Tambora meletus tahun 1815. Penelitian terhadap novel Tambora dilakukan dengan menganalisis struktur novel serta mengungkap sejarah meletusnya Gunung Tambora yang terkandung di dalamnya dengan menggunakan pendekatan sosiologi sastra. 


\section{Rumusan Masalah}

Berdasarkan latar belakang di atas terdapat tiga pokok permasalahan yang dibahas dalam penelitian ini. Pertama, Bagaimanakah struktur novel Tambora yang meliputi unsur penokohan, alur, dan latar?; Kedua, Bagaimanakah sejarah meletusnya Gunung Tambora yang dilukiskan dalam novel Tambora?; Ketiga, Aspek sosiologi apa sajakah yang terungkap dalam novel Tambora?

\section{Tujuan Penelitian}

Tujuan umum yang hendak dicapai dalam penelitian ini adalah untuk menambah wawasan pengetahuan, pemahaman dan perbendaharaan karya sastra khususnya sastra Indonesia. Secara khusus tujuan penelitian ini adalah, pertama, untuk mengetahui struktur novel Tambora. Kedua, mengetahui sejarah sebelum meletusnya Gunung Tambora. Ketiga, mengetahui aspek sosial yang terdapat dalam novel Tambora karya Agus Sumbogo.

\section{Metode dan Teknik Penelitian}

Metode dan teknik penelitian dibagi menjadi tiga, yaitu: (1) Metode dan Teknik Pengumpulan Data. Pada tahapan pengumpulan data, metode yang digunakan adalah metode studi pustaka dengan teknik lanjutan berupa teknik catat atau tulis. Sumber tertulis terdiri atas buku, majalah ilmiah, arsip, dokumen pribadi, dan dokumen resmi (Moleong, 1990:113). Data utama dalam analisis ini adalah struktur dan aspek sosiologis yang terdapat dalam novel Tambora. Objek dibaca secara intensif dan berulang-ulang, kemudian dicatat data yang penting. Data sebagai penunjang analisis diperoleh dari bukubuku teori yang menunjang penelitian ini. (2) Metode dan Teknik Analisis Data.
Dalam tahapan ini metode yang digunakan adalah metode formal dan metode deskriptif analisis. Metode formal adalah metode yang digunakan dalam analisis dengan mempertimbangkan aspek-aspek formal, aspek-aspek bentuk, yaitu unsur-unsur karya sastra (Ratna, 2009:49). Metode deskriptif analisis dilakukan dengan cara mendeskripsikan fakta-fakta yang kemudian disusul dengan analisis yang dapat dipertanggungjawabkan. Metode deskriptif tidak semata-mata menguraikan, melainkan juga memberikan pemahaman dan penjelasan secukupnya mengenai data yang ada (Ratna, 2009:53). Dalam pengolahan data dipergunakan teknik simak dan catat. Teknik simak dan catat merupakan lanjutan dari teknik membaca sebagai pengembangan terhadap pemahaman yang didapatkan dari proses membaca. (3) Metode dan Teknik Penyajian Hasil Analisis Data. Pada tahapan ini digunakan metode deskripsi, yakni dengan mendeskripsikan hasil analisis data yang telah dilakukan. Kemudian disusun ke dalam format penelitian berupa skripsi dengan menggunakan bahasa Indonesia ragam ilmiah. Data yang telah dikumpulkan, diolah, akhirnya disajikan. Metode yang digunakan dalam tahapan ini adalah metode informal. Metode informal menyajikan kaidah atau hasil penelitian secara verbalistis (menggunakan kalimat-kalimat). Artinya, penyajian data (hasil analisis) terurai dalam bentuk kata-kata bukan dalam bentuk angka-angka (Semi, 1993:24). Penyajian hasil pengolahan data menggunakan sistematika sebagai berikut. Bab I berisi pendahuluan yang merupakan pengembangan rancangan penelitian yang dilaksanakan. Pendahuluan terdiri atas latar belakang, rumusan masalah, tujuan penelitian, manfaat penelitian, penelitian 
sebelumnya, landasan teori, serta metode dan teknik penelitian analisis data. Bab II berisi analisis struktural novel Tambora karya Agus Sumbogo. Analisis struktural terdiri atas penokohan, alur, dan latar. Bab III berisi sejarah meletusnya Gunung Tambora yang dilukiskan dalam novel Tambora karya Agus Sumbogo. Bab IV berisi analisis sosiologi sastra novel Tambora karya Agus Sumbogo. Aspek yang terdapat pada bagian ini adalah aspek moral, aspek politik, aspek ekonomi, aspek kemasyarakatan, dan aspek budaya. Bab V merupakan penutup yang berisi simpulan dan saran.

\section{Hasil dan Pembahasan}

Analisis ini dapat disimpulkan bahwa, struktur novel Tambora karya Agus Sumbogo, yaitu: (1) Penokohan. Menurut Abrams (dalam Nurgiyantoro, 2005:165) penokohan adalah orang-orang yang ditampilkan dalam suatu karya sastra naratif atau drama oleh pembaca, ditafsirkan memiliki kualitas moral dan kecenderungan tertentu dalam melakukan tindakan. Penokohan dibagi menjadi dua, yaitu tokoh utama dan tokoh tambahan. Tokoh utama adalah tokoh yang menjadi sentral utama dalam cerita, menjadi ide, dan tema utama dalam cerita. Tokoh tambahan adalah tokoh yang mendukung cerita dan perwatakan tokoh utama.

Alur dibagi menjadi tiga bagian, yaitu tahapan awal, tahapan tengah, dan tahapan akhir. (1) Tahapan awal sebuah cerita biasanya disebut sebagai tahapan perkenalan. Tahapan perkenalan pada umumnya berisi sejumlah informasi penting yang berkaitan dengan berbagai hal yang akan dikisahkan pada tahapantahapan berikutnya. Fungsi pokok tahapan awal sebuah cerita adalah untuk memberikan informasi dan penjelasan seperlunya. Khususnya yang berkaitan dengan dengan latar dan penokohan (Nurgiyantoro, 2005:142). (2) Tahapan tengah adalah inti cerita yang disajikan seperti: tokoh memainkan peran, peristiwa penting yang dikisahkan, konflik berkembang semakin meruncing, menegangkan, dan mencapai klimaks (Nurgiyantoro, 2015:145). (3) Tahapan akhir menampilkan adegan tertentu sebagai akibat klimaks. Jadi tahapan ini berisi bagaimana kesudahan cerita, atau menyarankan pada hal bagaimanakah akhir sebuah cerita (Nurgiyantoro, 2005:146).

Latar dibagi menjadi tiga, yaitu: (1) Latar tempat, menyaran pada lokasi terjadinya peristiwa yang diceritakan dalam sebuah karya fiksi. Penggunaan latar tempat dengan nama-nama tertentu mencerminkan sifat dan keadaan geografis tempat yang bersangkutan (Nurgiyantoro, 2005:227). (2) Latar waktu berhubungan dengan masalah kapan terjadinya peristiwa-peristiwa yang diceritakan dalam sebuah karya fiksi. Masalah tersebut biasanya dihubungkan dengan waktu faktual, waktu yang ada kaitannya atau dapat dikaitkan dengan peristiwa sejarah (Nurgiyantoro, 2005:230). (3) Latar sosial berhubungan dengan perilaku kehidupan sosial masyarakat di suatu tempat yang diceritakan dalam karya fiksi. Tata cara kehidupan sosial masyarakat mencakup berbagai masalah ruang lingkup yang cukup kompleks, dapat berupa kebiasaan hidup, adat istiadat, keyakinan, pandangan hidup, cara berpikir dan bersikap, dan lain-lain tergolong latar spiritual. (Nurgiyantoro, 2005:233234).

Bahasan selanjutnya adalah sejarah meletusnya Gunung Tambora, bahasan ini merupakan perbandingan sejarah meletusnya Gunung tambora yang dijelaskan dalam novel dan dengan 
referensi sejarah Tambora lainnya. Selain itu, bagian ini juga membahas mengenai narasi sejarah yang dilukiskan dalam novel Tambora. Hal ini dapat dilihat pada beberapa bagian dalam isi novel merupakan sebuah narasi. Salah satu contoh narasi dalam novel ini adalah ketika penulis menceritakan bahwa tokoh utama dikirim ke masa lalu melalui gerbang ajaib.

Bahasan terakhir dalam penelitian ini adalah analisis sosiologi sastra novel Tambora. (1) Dalam Kamus Besar Bahasa Indonesia (2008:929) disebutkan bahwa moral adalah ajaran baik atau buruk yang diterima umum mengenai perbuatan, sikap, kewajiban, akhlak, dan budi pekerti. (2) Menurut Kamus Besar Bahasa Indonesia (2008:1091) politik adalah pengetahuan mengenai ketatanegaraan seperti sistem pemerintahan dan dasar pemerintahan. Secara umum, politik merupakan sebuah tahapan untuk membentuk atau membangun kekuasaan di dalam masyarakat yang berguna untuk mengambil keputusan yang terkait dengan kondisi masyarakat. (3) Menurut Kamus Besar Bahasa Indonesia (2008:355), ekonomi adalah ilmu mengenai asas-asas produksi, distribusi, dan pemakaian barang-barang, serta kekayaan seperti, keuangan, perindustrian, dan perdagangan. Ekonomi adalah ilmu yang mempelajari bagaimana manusia berusaha mencapai kemakmurannya. (4) Aspek kemasyarakatan merupakan aspek yang berhubungan dengan kejadian-kejadian dalam kehidupan sehari-hari di dalam masyarakt, seperti etika, pergaulan, kemanusiaan, dan budaya (Soekanto, dalam Khairi, 2016:51).

\section{Simpulan}

Berdasarkan analisis dalam bab-bab sebelumnya, penelitian ini diakhiri dengan simpulan sebagai berikut. Novel Tambora karya Agus Sumbogo, sebuah novel yang menceritakan perjalanan Lesly dan teman-temannya ke masa lalu sebelum peristiwa letusan Gunung Tambora terjadi. Lesly dan temantemannya dikirim ke masa lalu untuk mengungkapkan sejarah dan fenomena yang terjadi sebelum Gunung Tambora meletus dan kembali ke masa depan.

Tokoh utama adalah tokoh yang diberikan kepercayaan oleh Orang Sakti untuk mengembalikan barang berharga milik masyarakat Tambora. Sedangkan, tokoh tambahan adalah tokoh yang ditugaskan untuk menemani tokoh utama dalam ekspedisi tersebut.

Alur dalam novel Tambora disusun secara kronologis. Novel ini menggunakan alur mundur (flashback), Mulai dari tahapan awal, menjelaskan kejadian utama yang diceritakan dalam novel dan awal mula tokoh mengetahui barang milik masyarakat Tambora yang harus dikembalikan ke pemilik sebenarnya. Tahapan kedua, menggambarkan konflik yang terjadi dalam novel yang melibatkan tokoh. Dan tahapan ketiga, menggambarkan akhir dari perjalanan tokoh dari masa lalu hingga kembali ke masa depan.

Novel Tambora berlatar di beberapa tempat yaitu, Rhode Island, Bali, dan Pulau Sumbawa. Rhode Island merupakan tempat tinggal tokoh utama. Latar waktu pada novel ini adalah tahun 2000-an ketika Prof. Thomas mengambil barang milik masyarakat Tambora dan Lesly diutus untuk mengembalikan barang tersebut. Selain itu, latar waktu yang digambarkan oleh penulis dalam 
novel tersebut adalah tahun 1815 ketika perjalanan Lesly dan teman-temannya ke masa lalu dan tiba di tahun 1815 sebelum letusan Gunung Tambora. Selanjutnya, latar sosial pada novel Tambora adalah masyarakat yang masih sangat terbelakang dan takut akibat orang-orang Belanda yang ingin menguasai wilayah jajahannya.

Pada bahasan terakhir pada bab ini adalah sejarah yang terungkap sebelum Gunung Tambora meletus. Sejarah yang ditemukan oleh para tokoh adalah penemuan barang-barang peninggalan masyarakat di tiga kesultanan tersebut. Dijelaskan juga sejarah yang diungkapkan pada referensi lain seperti ulasan-ulasan yang membahas mengenai sejarah letusan Gunung Tambora.

Analisis sosiologi sastra dalam novel Tambora meliputi beberapa aspek, yaitu aspek moral, aspek politik, aspek ekonomi, aspek kemasyarakatan, dan aspek budaya. Pada aspek moral baik dan moral yang kurang baik. Aspek politik yang terjadi dalam novel adalah politik adu domba. Aspek Ekonomi dalam novel Tambora adalah sebagian besar masyarakat Tambora bekerja sebagai pedagang dan buruh perkebunan. Aspek kemasyarakatan dalam novel mencakup hubungan antarmasyarakat, tokoh dengan masyarakat, dan orang-orang Belanda dengan masyarakat. Dan yang terakhir adalah aspek budaya yang terdapat dalam novel adalah sebuah upacara heko rasa yang biasa digelar oleh sultan dan para pejabat kesultanan dengan mengundang para rakyat untuk ikut merasakan kebahagiaan.

\section{Daftar Pustaka}

Damono, Sapardi Djoko. 2014. Sosiologi Sastra: Pengantar Ringkas. Jakarta:
Pusat Pembinaan dan Pengembangan Bahasa.

Departemen Pendidikan Nasional. 2008. Kamus Besar Bahasa Indonesia. Edisi Keempat. Jakarta: PT Gramedia Pustaka.

Khairi, Fathul. 2016. "Analisis Sosiologi Sastra Novel Anak Bakumpai Terakhir Karya Yuni Nurmalia". Skripsi Fakultas Ilmu Budaya, Universitas Udayana, Denpasar.

Moleong, Lexy J. 1990. Metode Penelitian Kualitatif. Bandung: Remaja Rosdakarya.

Nurgiyantoro, Burhan. 2005. Teori Pengkajian Fiksi. Cetakan kelima. Yogyakarta: Gadjah Mada University Press.

Ratna, Nyoman Kutha. 2009. Teori, Metode, dan Teknik Penelitian Sastra. Yogyakarta: Pustaka Pelajar.

Rusyanti, Hetty. 2015. "Teori Bahasa: Contoh Karangan, Definisi Narasi, Karangan.Narasi'"kajianteori.com..htt p://www.kajianteori.com/2015/03/pe ngertian-karangan-narasi.html. Diakses 22 Januari 2017.

Semi, Atar. 1993. Metode Penelitian sastra. Bandung: Angkasa. 